\title{
EGYPT ON THE BRINK
}

Tarek Osman is an Egyptian political economist with fifteen years' experience in strategy consulting, finance, and politicaleconomy advisory. He has advised leading international development agencies, corporations and financial institutions on the Arab world. His writings have appeared or been cited in the Financial Times, The Economist, Foreign Policy, Foreign Affairs, the Guardian and the Boston Globe, amongst many others. He is a regular commentator on the Arab world at leading thinktanks, conferences, and international news stations. He studied at the American University in Cairo, Egypt, and Bocconi University in Milan, Italy. He lives in Cairo and London. 

TAREK OSMAN

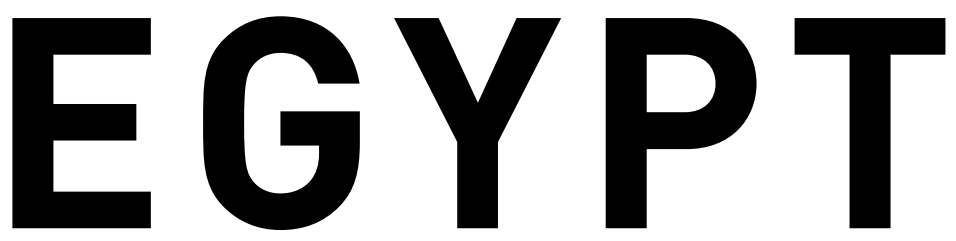

ON THE BRINK

FROM NASSER TO

THE MUSLIM BROTHERHOOD

YALE UNIVERSITY PRESS

NEW HAVEN AND LONDON 
Copyright (C) 2010, 2011, 2013 Tarek Osman

This revised edition published 2013 .

The right of Tarek Osman to be identified as author of this work has been asserted by him in accordance with the Copyright, Designs and Patents Act 1988.

All rights reserved. This book may not be reproduced in whole or in part, in any form (beyond that copying permitted by Sections 107 and 108 of the U.S. Copyright Law and except by reviewers for the public press) without written permission from the publishers.

For information about this and other Yale University Press publications, please contact:

U.S. Office: sales.press@yale.edu yalebooks.com

Europe Office: sales@yaleup.co.uk www.yalebooks.co.uk

Set in Janson by IDSUK (DataConnection) Ltd.

Printed in Great Britain by Hobbs The Printers Ltd, Totton, Hampshire

Library of Congress Cataloging-in-Publication Data

Osman, Tarek.

Egypt on the brink: from Nasser to Mubarak / Tarek Osman. p. $\mathrm{cm}$.

ISBN 978-0-300-177268 (cl: alk. paper)

1. Egypt-History-1952-1970. 2. Egypt-History-1970-1981.

3. Egypt-History-1981-4. Egypt-Social conditions-1952-1970.

5. Egypt-Social conditions-1970-1981. 6. Egypt-Social conditions1981- I.

Title.

DT107.83.O76 2010

$962.05-\mathrm{dc} 22$

A catalogue record for this book is available from the British Library.

ISBN 978-0-300-19869-0

10987654321

20172016201520142013 